\title{
Taxing Micro, Small and Medium Enterprises in Yogyakarta: Regulation and Compliance
}

\author{
Siti Rahma Novikasari ${ }^{\mathrm{a}, 1, *}$, Duc Quang $\mathrm{Ly}^{\mathrm{b}, 2}$, Kerry Gershaneck ${ }^{\mathrm{b}, 3}$ \\ ${ }^{a}$ Faculty of Law, Universitas Islam Indonesia, Yogyakarta, Indonesia \\ ${ }^{\mathrm{b}}$ Senior Research in German-Southeast Asian Center of Excellence for Public Policy and Good Governance, German \\ ${ }^{1}$ siti.rahma.novikasari@uii.ac.id*, ${ }^{2}$ ducquangly@hotmail.com, ${ }^{3}$ kerrygershaneckcpg@ hotmail.com \\ * corresponding author
}

\section{ARTICLE INFO}

Article history

Received: March 9, 2021

Revised: July 7, 2021

Accepted: July 18, 2021

Keywords

Tax Compliance

Final Income Tax Regulation

Micro

Small

Medium Enterprises

\section{ABSTRACT}

The Special Region of Yogyakarta is a region with prominent Micro, Small, and Medium Enterprises (MSMEs) actors in Indonesia. This invites the important question of whether the implementation of the new MSMEs tax regulations in the region impacts the intensification of final income tax and tax compliance. This study aims to analyze the relationship between the amendments of the final income tax policy and the legal compliance of MSMEs taxpayers. This research uses a juridical and empirical approach. Empirical data was collected by interview and questionnaire to seven taxpayers, while juridical data was obtained by analyzing the Government Policy on taxation. This study shows that the reduction of the final income tax tariff from $1 \%$ to $0.5 \%$ and the existence of legal certainty regarding the taxation time frame implies a positive impact on taxpayer compliance. This is demonstrated by the fact that the number of taxpayers in 2019 increased by $15 \%$ when compared to 2017 . However, tariff reduction is not the solution to the non-compliant taxpayer. The Regional Office of the Directorate General of Taxes still found the tax avoidance. It means the government needs to conduct a more cooperative approach to improve MSMEs taxpayer compliance.

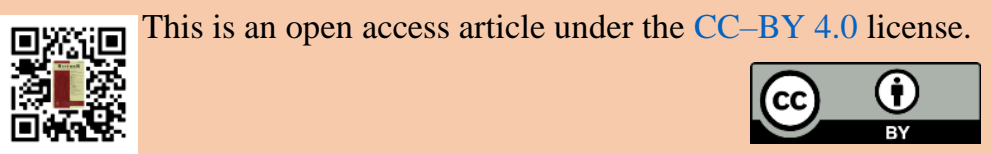

\section{Introduction}

The budgetary function is the main function of the tax, which is used to finance government activities (Castro \& Scartascini, 2015). Currently, more than $80 \%$ of state revenue comes from the taxation sector. It proves that taxes have an important role in the running of the government. Income tax is one of the sources of state revenue borne by individual or corporate taxpayers on their income as a tax object. The legal definition of income as a tax object is any additional economic capability received or obtained by the taxpayer, whether originating from Indonesia or outside Indonesia, which can be used for consumption or to increase the wealth of the taxpayer concerned, under whatever name and form. The types of income tax objects have been regulated in Article 4 of Law No. 7 of 1983 concerning Income Tax as amended several times, most recently by Law No. 11 of 2020 (hereinafter referred to as the Income Tax Law).

To optimize the state revenue, Article 4 paragraph (2) letter e and Article 17 paragraph (7) of the Income Tax Law legally authorize the government to determine Final Income Tax on certain other 
incomes. One of the final income taxes in Indonesia is the tax imposed on the business income received or earned by taxpayers with a certain gross circulation. General income tax and final income tax have different concepts and regulations. The general income tax uses a progressive tariff and a basis of taxable income. While the final income tax uses a proportional tariff and gross circulation income as the tax base.

Following up on the delegation of these provisions, the government established a final income tax policy through a Government Regulation. The policy issued for the first time was Government Regulation No. 46 of 2013 concerning Income Tax on Income from Businesses Received or Earned by Taxpayers with Certain Gross Circulation (hereinafter referred to as Government Regulation No. 46 of 2013). Business actors such as Micro, Small, and Medium Enterprises (MSME actors) have a gross income below 4.800.000.000. rupiah in one tax year qualified as taxpayers on final income tax. So, this policy is generally known as the MSMEs tax. The tax policy for MSME has no orientation towards a budgetary function but rather a regular function as a tax incentive for MSME actors. Based on Black Law Dictionary, tax incentive means exemption or a deduction from a tax that is given to entice people to engage in the action with the tax exemption. The incentive provided was a tariff reduction to $1 \%$ of the business gross circulation of MSME actors. The imposition of Final Income Tax is determined based on the consideration of the need for simplicity in tax collection.

Final income tax for MSME actors using a self-assessment system that gives taxpayers trust to calculate, deposit, and report the Income Tax payable. The logical consequence of this system is the importance of voluntary tax compliance. Voluntary Tax Compliance is a tax system based on taxpayers complying with the tax laws without being compelled by the tax authority to do so (Jimenez \& Iyer, 2016). Taxpayers are deemed to comply if they have fulfilled their tax obligations. Taxpayer compliance criteria are also regulated in Article 3 paragraph (2) of the Minister of Finance Regulation No. 198 / PMK.03 / 2013 concerning Preliminary Returns of Overpayment of Taxes for Taxpayers Who Meet Certain Requirements, the criteria include: a) compliance in submitting tax returns; b) compliance in paying off taxes payable; and c) the accuracy of tax returns for the previous tax period, part of the tax year, and the previous tax year.

In 2017 Indonesian MSME actors reached 60 million. However, only $2.3 \%$ or 1.4 million MSME actors have taxpayer-identification numbers and are registered at the Directorate General of Taxes and comply with the obligation stipulated in regulation related. As announced by the Minister of Finance, the potential state revenue from the MSME sector in 2018 was around 5.7 billion rupiahs and continues to grow. Referring to the Income Tax Law, MSME actors have fulfilled the subjective and objective elements to be imposed with income tax. So, the consequence is that MSMEs actor must carry out their obligations in the field of taxation. The imposition of income tax for MSME actors is important to narrow the tax gap in Indonesia.

This policy was evaluated and amended by Government Regulation No. 23 of 2018 concerning Income Tax on Business Income Received or Earned by Taxpayers with Certain Gross Circulation (hereinafter referred to as Government Regulation No. 23 of 2018). In Government Regulation Number 23 of 2018, there is a reduction in the final income tax tariff for MSMEs to $0.5 \%$. Tariff reduction is used as an instrument to increase taxpayer compliance and it is expected to increase state revenue from the taxation sector (Purnawan et al., 2019).

In the context of the implementation of MSME tax regulations in the Special Region of Yogyakarta as a region with large MSME actors in Indonesia, this policy has a low impact on the intensification of final income tax, and tax compliance. MSMEs in Yogyakarta are dominated by the manufacturing, trade, and agriculture sectors. The average annual gross income for micro-enterprise is 26.063 .802 rupiahs, small-enterprise is 96.199 .162 rupiahs and medium-enterprise is 114.711 .996 rupiahs. Data from the Regional Office of the Directorate General of Taxes of the Special Region of Yogyakarta showed only $1 \%$ of the total 230,000 MSME actors made tax payments in the first semester of 2017. Most of the MSME actors lack awareness and willingness to register as taxpayers and get taxpayer identification numbers.

With the issuance of Government Regulation 23 of 2018 as a substitute for Government Regulation No. 46 of 2013. This article is intended to capture the impact of policy amendment on tax compliance of MSMEs actors in Yogyakarta. Research questions arose are: First, how does the final income tax policy impact MSME taxpayers' compliance in Yogyakarta? Second, what are the legal compliance 
constraints of MSME taxpayers? This study aims to examine the relationship between the amendments to the final income tax policy with MSMEs taxpayer legal compliance. In addition, it also examines the constraints of taxpayers to comply with tax law. So that it can provide suggestions for improvement of taxation policy is and increasing taxpayer compliance.

\section{Research Methods}

This research is juridical-empirical which is legal research on the enactment or implementation of normative law in action against a legal event in society. The approach used in this research was the statute approach and the conceptual approach. Field research was carried out to obtain primary data by interviewing and questionnaire methods to seven final income taxpayers engaged in the MSME sector in the Special Region of Yogyakarta. Seven MSME respondents from Sleman, Bantul, Kulon Progo and Jogja cities were determined by random sampling. The MSMEs are engaged in trade in food, fashion, culinary, handicrafts, bridal makeup services, and transportation services. To strengthen this study, primary data was also extracted at the Regional Office of the Directorate General of Taxes of the Special Region of Yogyakarta as the tax authority. Secondary data was obtained by conduct a literature study on legal materials, books, journals, and related reports.

\section{Discussion}

\subsection{Impact of Final Income Tax Regulation on Tax Compliance}

The final income tax collection model is known as the presumptive regime, where the tax is imposed by an assumed condition of the taxpayer (Juniarti et al., 2019). This model is commonly used in non-member countries of the Organization for Economic Co-operation and Development (OECD), such as Indonesia, developing countries with characteristics hard to tax society and lack capability in bookkeeping (Dewi \& ER, 2019). Final income tax for MSME actors is legally regulated in Article 4 paragraph (2) letter e as "other certain income classifications" and Article 17 paragraph (7) of the Income Tax Law. Below are some Government Regulations are promulgated as a further specific rule to these provisions that are mentioned in table 1 .

Table 1. Comparison of Final Income Tax Regulations

\begin{tabular}{|c|c|c|}
\hline & $\begin{array}{c}\text { Government Regulation } \\
\text { No. } 46 \text { of } 2013\end{array}$ & $\begin{array}{c}\text { Government Regulation } \\
\text { No. } 23 \text { of } 2018\end{array}$ \\
\hline Taxpayer & $\begin{array}{l}\text { Individual taxpayers or corporate taxpayers } \\
\text { exclude the permanent establishment } \\
\text { (Article } 2 \text { number (2) letter a) }\end{array}$ & $\begin{array}{l}\text { Individual taxpayers and corporate taxpayers } \\
\text { in the form of cooperatives, limited } \\
\text { partnership, firms, or limited liability } \\
\text { companies } \\
\text { (Article } 3 \text { paragraph 1) }\end{array}$ \\
\hline Tax Object & $\begin{array}{l}\text { Income from business, excluding income from } \\
\text { services related to independent work, with the } \\
\text { gross circulation no more than Rp. } \\
4,800,000,000 \text { (four billion eight hundred } \\
\text { million rupiah) in } 1 \text { tax year } \\
\text { (Article } 2 \text { paragraph (2) letter b) }\end{array}$ & $\begin{array}{l}\text { Income from business received or obtained by } \\
\text { domestic taxpayers with a certain gross } \\
\text { circulation does not exceed Rp. } 4,800,000,000 \\
\text { (four billion eight hundred million rupiah) in } 1 \\
\text { tax year } \\
\text { (Article } 2 \text { paragraph } 1 \text { in conjunction with } 3 \\
\text { paragraph 1) } \\
\text { Total gross circulation of business, including } \\
\text { gross circulation from branches (Article } 4 \\
\text { paragraph 1) }\end{array}$ \\
\hline Tax Rate & $\begin{array}{l}1 \% \\
\text { (Article } 3 \text { paragraph (1)) }\end{array}$ & $\begin{array}{l}0,5 \% \\
\text { (Article } 2 \text { paragraph }(2))\end{array}$ \\
\hline Tax based & $\begin{array}{l}\text { Total gross circulation per month } \\
\text { (Article } 4 \text { paragraph (1)) }\end{array}$ & $\begin{array}{l}\text { Total gross circulation of income from the } \\
\text { business each month. Is a compensation or } \\
\text { replacement value in the form of money or } \\
\text { value received or obtained from the business } \\
\text { before deducting sales, cash, or similar } \\
\text { discounts (Article } 6 \text { paragraph (1)) }\end{array}$ \\
\hline Timeframe & Unregulated & $\begin{array}{l}\text { The maximum period for the imposition of } \\
\text { Final income tax: } \\
\text { - } 7 \text { years for an individual taxpayer }\end{array}$ \\
\hline
\end{tabular}




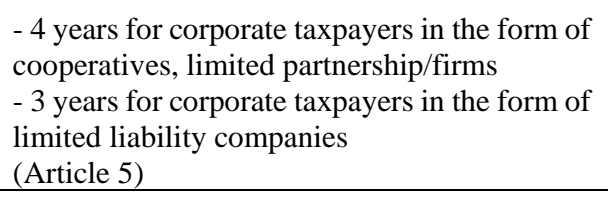

Table 1 shows in existing policy which is Government Regulation 23 of 2018 provides the convenience of tariff and certain regulations on tax collection mechanisms. There are two fundamental changes in the Final Income Tax Policy. First, the reduction of tax tariff which was originally set at $1 \%$ reduced through the existing policy to $0.5 \%$. Second, clarity of timeframe for imposing the tariff for individual and corporate taxpayers. This latest final income tax policy is aimed at optimizing the intensification of final income taxpayers, increasing public participation in economic activities, providing convenience and justice for taxpayers. The provision of times period on levying the $0,5 \%$ tariff is aimed to prepare the taxpayers to comply with business bookkeeping obligations as a taxpayer of general income tax.

One of the taxpayers who are the target of the final income tax policy is MSME actors with a gross income below 4,800,000,000 rupiahs in one tax year. The MSME category has been rigidly regulated in Law No. 20 of 2008 on Micro, Small, and Medium Enterprises. MSME has various business sectors ranging from industrial, service, agriculture, plantation sectors, and so on. The existence of MSME is one of the main pillars of the national economy because it has an important role in absorbing employment, equitable distribution and increasing people's income, increasing economic growth, and realizing national stability (Yáñez-Araque et al., 2021). So that the government needs to provide support in the form of ease of capital, tax facilities to legal protection.

However, considering that the income tax collection system uses the Self-Assessment System, the tax collection process depends on the legal compliance of taxpayers to register, doing bookkeeping, report gross income, and pay the taxes payable to the government. Legal compliance with tax obligations is hereinafter referred to as tax compliance. According to Roth, tax compliance is a legal definition that means "filing all required tax returns at the proper time and that returns accurately report tax liability in accordance with the tax law applicable at the time the return is filed." This opinion was later strengthened by James and Alley (2002): "tax compliance refers to the willingness of individuals to act in accordance with both the 'spirit' and the 'letter' of the tax law and administration without the application of enforcement activity" (Saad, 2014).

Another indicator was also mentioned by Norman D. Nowak, that there are criteria that must be met for a taxpayer to be classified as tax compliance, including a) Taxpayers understand or try to understand all the provisions of tax laws and regulations; b) Fill out the tax return completely and clearly; c) Calculate the amount of taxes payable correctly; and d) Pay taxes payable on time. In line with Norman D. Nowak's viewpoint, Chaizi Nasucha provides identification of tax compliance criteria (Li et al., 2020), including a) Taxpayer compliance in registering; b) Compliance to resubmit the tax return; c) Compliance in calculating and paying taxes payable; and d) Compliance with the payment of arrears.

In the self-assessment system model that is applied to the Final Income Tax, several voluntary tax compliance criteria are required must be met by taxpayers for the success of tax collection (Hajawiyah et al., 2021), namely, first, tax consciousness. Taxpayers have a willingness to automatically carry out their tax obligations such as registering, calculating, paying, and reporting the amount of taxes payable. Second, tax honesty. Taxpayers carry out their obligations properly without any manipulation, this is needed in this system because the tax authorities give the taxpayers trust to calculate, deposit, and report the amount of taxes payable by themselves. Third, tax mindedness. In addition to having an awareness of their tax obligations, taxpayers also have a high desire to pay taxes payable, such as allocating funds for taxes and preparing the required documents and consulting. Fourth, tax discipline. Taxpayers in carrying out tax obligations are carried out promptly under the prevailing rules and regulations.

Based on the various criteria and indicators mentioned above, the authors draw several indicators to be used as instruments to analyze the implementation of voluntary tax compliance of taxpayers. First, Taxpayer compliance in submitting tax returns completely and clearly and paying taxes payable 
on time. Below are some number of MSMEs as Final PPH Taxpayers in 2017 and 2019 in Special Region of Yogyakarta that are mentioned in table 2.

Table 2. Number of MSMEs as Final PPH Taxpayers in 2017 and 2019 in Special Region of Yogyakarta

\begin{tabular}{ccc}
\hline & $\mathbf{2 0 1 7}$ & $\mathbf{2 0 1 9}$ \\
\hline Number of MSME & 230.000 MSME & 250.000 MSEM \\
Final Income Taxpayer & 2.300 Taxpayer & 41.000 Taxpayer \\
Percentage & $1 \%$ & $16,5 \%$ \\
\hline
\end{tabular}

${ }^{a}$ Data processed from the Regional Office of the Directorate General of Taxes and the Department of Cooperatives and MSME Special Region of Yogyakarta

Table 2 shows there are changes in tax policy for taxpayer businesses with certain gross circulation through Government Regulation No. 23 of 2018 are an instrument for the tax authorities to extend and intensify Final Income Taxpayers. The Regional Office of the Directorate General of Taxes and the work units under it (District/City Primary Service Offices) undertake various efforts such as cooperation with banks, socialization, and visits to MSMEs. From table 2 above shows that after the issuance of Government Regulation No. 23 of 2018 and various extensification and intensification programs carried out by the tax authorities, in 2019 there were $\pm 41,000$ taxpayers who are MSME actors registered as taxpayers in Yogyakarta. They carried out tax obligations by getting taxpayer identification numbers, filling out an annual tax return, and pay taxes payable on time under the relevant provisions. The increase in the number of final income taxpayers by $15.5 \%$ was an impact of the tariff reduction policy and the certainty of the imposition period.

The issuance of Government Regulation No. 23 of 2018 is not only intended for budgetary purposes but also efforts to implement the regulated function of taxes, The tariff is used by the government as an instrument to bring the people (taxpayers) to the expected conditions. The expected conditions refer to the explanation of Government Regulation No. 23 of 2018 that this rule is intended to provide convenience and simplicity of the implementation of tax obligations for taxpayers, and the existence of a period of application of rates are intended as a learning period for taxpayers to be able to do bookkeeping before being subject to general Income Tax (Article 17 of the Income Tax Law).

The related policy is also called tax expenditure, namely the transfer of resources to the public through a reduction in tax obligations. Tax Expenditures are defined as "revenue losses attributable to provisions of Federal tax law which allow a special exclusion, exemption, or deduction from gross income or which provide a special credit, a preferential rate of tax, or a deferral of tax liability. These exceptions are often viewed as alternatives to other policy instruments, such as spending or regulatory programs" (Luksic, 2020). Specifically, it refers to the distribution of tax expenditure types according to the OECD, tax expenditure regulated in Government Regulation No. 23 of 2018 is a tariff/rate relief (Oliviero \& Scognamiglio, 2019). Tariff reduction of the Income Tax for a certain period takes effect in reducing or delaying state income from tax payments. Meanwhile, the tax burden of taxpayers is reduced due to the reduction in the rate. The existence of special tariff provisions that are different from general tax provisions or the benchmark tax system has subject and object targets of tax with certain requirements aimed at supporting the economy (Lagravinese et al., 2020).

Through tariff reduction and various incentive facilities, the Government is trying to encourage the development of MSMEs while providing opportunities for the community to contribute to financing development through tax payments. It is hoped that the public can continue to increase their awareness and compliance with tax rights and obligations. So that the taxpayers of MSMEs will get additional capital savings that can be used to develop the business to improve the standard of living and welfare of taxpayers (Tondani, 2009). With this tax expenditure policy, Final Income Taxpayers are expected to increase tax consciousness and tax discipline in carrying out tax obligations.

Second, Taxpayer compliance to submits a tax return, calculate, and pay taxes payable correctly. The compliance ratio of submitting a tax return and paying taxes payable of $71.10 \%$. From the information provided by the Head of the Regional Office of the Directorate General of Taxes of the Special Region of Yogyakarta, in the audit conducted by the tax authorities, it was found that the gross circulation reported by the final income taxpayers in the tax return did not match to the actual monthly gross circulation. With a logical consequence, the taxes payable paid by the taxpayer does not match with the tax debt that should be paid on a tax basis in the form of the real gross circulation of the 
taxpayer's business. The untruth, incompleteness, and obscurity of the Taxpayer's data in the Tax Return, can cause tax revenue to be inefficient and ineffective (Hanlon \& Heitzman, 2010).

Third, Taxpayer compliance to understand the provisions of tax laws and regulations. There is legal fiction igronantia iuris neminem excusat it means everyone is supposed to know the law (Deakin et al., 2017). Understanding tax laws and regulations is also an indicator of voluntary tax compliance initiated by Norman D. Nowak. From the research conducted by the author, $43 \%$ of the respondents stated read up MSME tax regulation independently, took a tax course when starting a business, or because of their educational background.

Meanwhile, $57 \%$ of the respondents stated that they did not read and/or understand the Income Tax Law and tax policies related to MSME. Poor understanding of tax policy is one of the constraints in tax compliance. This condition can be caused by several factors: a) taxpayers do not have basic skills in understanding regulatory norms; b) taxpayers do not have the will to study independently or through courses; c) taxpayers consider tax knowledge less impact on the progress of their business. and d) rely on socialization programs provide by tax authorities or information from banks when applying for business financing.

\subsection{Legal Framework Legal Compliance Constraints of MSME Taxpayers}

From the discussion above, Government Regulation No. 23 of 2018 has a positive impact, there is a progressive trend in increasing the number of taxpayers from 1\% in 2017 to $16,5 \%$ in 2019. Furthermore, \pm 41.000 taxpayers comply to submit a tax return and pay the taxes payable on time. Nevertheless, the tax gap in the MSME sector is still quite high. There are $\pm 209,000$ or as much as 83.5\% of the total MSME actors in Yogyakarta who have not been registered as taxpayers and have not carried out their tax obligations.

The theories of tax compliance behavior that describe the non-compliance actions of taxpayers continue to develop. The results of Jackson and Miliron's (1986) research provide categories that encourage non-compliance, namely tax complexity (tax audit, tax penalty, and tax rates), attitude and perception (tax morale, tax fairness, and peer influence), demographic characteristics (age, gender, and education), and non-compliance opportunity (income level, occupation, and income source). Assessed tax compliance using three variables, namely the ethical/moral tax variable, the equity/fairness variable, and the deterrence measures variables) (Huong \& Cuong, 2019). Combines the determinants of tax compliance behavior that have been developed by previous experts, including tax complexity, tax audit, tax morale, tax fairness, peer influence, tax service quality, and tax knowledge (Robbins \& Kiser, 2020).

Based on the theoretical framework regarding tax compliance behavior above, empirical research conducted on MSME actors in Yogyakarta shows that several constraints cause non-compliance. Those constraints are regarding tax knowledge, tax service quality that caused tax distrust, and tax morale.

First, low understanding of tax regulation (tax knowledge). Second, distrust between taxpayers and tax authorities causes a lack of tax morale. Tax knowledge is an important aspect of the selfassessment system applied to income tax. According to Harris (1989), taxation knowledge is divided into two aspects, namely taxation knowledge which is intended to provide an understanding of taxation laws and regulations to improve taxpayer compliance. On the other hand, the understanding of taxation is used by taxpayers to take tax evasion actions. Both aspects of understanding taxation are obstacles to the tax compliance by taxpayers (Saad, 2014). 57\% of the respondents have lack understanding of the tax law provisions. Constraint in understanding the tax law and lack of socialization from tax authority are the main reasons. This lack of understanding might be a potential cause for submitting incomplete tax returns and incorrect calculation of the amount of taxes payable.

This condition causes the tax authority to consider that the level of tax compliance of taxpayers is low. The low intellectual level and the understanding of tax law and regulation tend to be the cause of passive tax resistance, a form of tax avoidance that does not originate from the taxpayer's initiative (Soewardi \& Ananda, 2015). This has an impact on public awareness and compliance in paying taxes, so that passive resistance to taxes is inevitable. Passive resistance by MSME actors also leads by the low ability of taxpayers to conduct bookkeeping their business. The bookkeeping held by EMSM confounds both personal and business financial records. 
This is against the provision of Article 28 of the Law on General Provisions and Tax Procedures, that the recording as referred to in paragraph (2) consists of data collected regularly on gross revenue and/or gross income as a basis for calculating the amount of tax owed, including income not subject to tax and/or subject to final tax. Most of the final income taxpayers have no understanding that submitting an incorrect or incomplete tax notification letter and falsified business records/bookkeeping are tax crimes. This condition is in line with the results of research by Otusanya who showed that small business owners obtained significantly lower tax literacy scores than other study participants such as fiscal officials or business students. Because tax knowledge correlates with tax revenue, this finding contributes to an understanding of the observed low compliance rates among small entrepreneurs (Otusanya, 2011). So, to increase compliance, taxpayers should understand their rights, obligation, and procedure of paying taxes (Duy \& Tran, 2021). The knowledge of tax regulation should be improved by taxpayers themselves in collaboration with socialization from the tax authority.

Second, another cause of non-compliance with tax obligations is the public distrust of the government as the tax authority (tax distrust). Tax authorities demand taxpayers fulfill their obligations by imposing administrative fines for errors in filling out tax returns, late payment of taxes, and so on. However, on the other hand, not all taxpayers get excellent public services quality from the tax authorities, such as not being included in Business Development Services (BDS) activities. The BDS program is a tax extensification strategy as stated in the Decree of the Director-General of Taxes Number KEP-95/PJ/2015 concerning the Strategic Plan of the Directorate General of Taxes 20152019. To provide BDS services to EMSM taxpayers, the tax authority collaborates with various agencies, institutions, associations, and other parties to provide various services and facilities in the field of taxation and business development. Cooperation between the tax authority and BDS provider aimed to improve MSME performance, access to markets, and ability to compete (Nugroho, 2015).

Some efforts have been done by the Regional Office of the Directorate General of Taxes of the Special Region of Yogyakarta to extend and intensify taxation and increase the tax compliance of final income taxpayers are:

1. Business financing activities by banks that have been appointed by the government to MSME actors who already have a tax identification number and registered as a final income taxpayer;

2. Conducting various BDS activities with accomplished MSME actors, as for development activities that have been carried out such as learning digital marketing together with Bukalapak;

3. Facilitate clearning business records and bookkeeping with various universities and tax centers for MSME actors with a gross circulation below 4.800.000.000 rupiahs or those starting to approach 4.800.000.000 rupiahs within the timeframe determined by Government Regulation No 23 of 2018. Tax education held through social media and by visiting to business locations to increase the willingness of MSME actors to register as taxpayers.

Distrust to the tax authority arises when not all taxpayers get BDS program facilities. Taxpayers concluded that the fulfillment of tax obligations just a requirement for MSME actors to get business loans from banks. Moreover, the high level of corruption committed by state officials using the state and regional budgets sourced from tax revenues is the cause of the drop in taxpayer trust in the government (Le et al., 2020). This is one of the obstacles to optimizing state revenue from the tax sector. The taxpayer's distrust of the tax authorities has implications for low tax morale, which indicates an intrinsic motivation to comply and pay taxes voluntarily.

Third, moral taxation is a basic motivation that encourages taxpayers to comply with voluntary compliance, (Torgler \& Schneider, 2009) these basic motivations include intrinsic motivation that comes from the taxpayer, such as pride in compliance and guilt over non-compliance, there is a reciprocal relationship between taxpayers and the government as indicated by the existence of excellent tax compliance and public service providers in the taxation sector, the influence of the community environment, and intergenerational values are embedded as a community culture where there is awareness of tax obligations as an implementation of the principle of cooperation in national development. 
Lack of tax morale can cause taxpayers to take active resistance. Active resistance is taxpayer's initiative efforts, directly addressed to the tax authorities to avoid taxes or reduce the tax obligations that should be paid. The active resistance carried out by the taxpayer is carried out to reduce, embezzle, smuggle, and eliminate the tax burden that should be paid to result in a reduced proportion of state revenue from the tax sector. The active resistance efforts of taxpayers can be categorized as tax evasion, an unlawful act to eliminate and/or reduce the amount of tax payment (Szablowski \& Campbell, 2019). Responding to the various tax compliance constraints above, increasing tax morale and preventing tax crimes, the tax authority needs to adjust a cooperative compliance approach.

Based on OECD Forum on Tax Administration, cooperative compliance means "real time cooperation with tax authorities resulting in the payment of taxes on time in an effective and efficient manner on the understanding that the tax payer can be trusted and the tax administration behaves predictably and provide certainty", cooperative compliance is approach based on trust and dialogue between both parties (Kirchler et al., 2003). In this approach, both parties have equal obligations to conduct. Taxpayers must obey their tax obligations, while tax authorities carry out public services such as giving proactive tax supervision and facilities equally. Building a strong relationship and trust with taxpayers by strengthening bureaucratic reform and anti-corruption commitment.

\section{Conclusion}

There are two conclusions regarding the legal problems that have been raised and elaborated on. First, the amendment in the final income tax tariff as a tax facility for business actors with gross revenue below 4.800.000.000 rupiahs has a progressive impact on the increasing tax compliance, especially in carrying out registration obligations, submitting complete and clear tax notification letters, and pay the tax debts on time. Changes in tariff as tax expenditure have implications for reduced tax revenue for a certain period. The positive trend of Government Regulation No. 23 of 2018 in Yogyakarta was proven by the addition of 18,000 new MSME taxpayers in 2019 or an increase of $15.5 \%$ in total. But taxpayers still lack an understanding of tax laws and regulations. Obligations to complete and correct calculating and paying tax debt still tend to be low. Second, with the issuance of Government Regulation Number 23 of 2018 in Yogyakarta as the legal basis for taxation for MSMEs, several compliance constraints were still found. Lack of taxpayer understanding of taxation provisions (tax knowledge) results in passive resistance of taxpayers. Distrust between taxpayers and the government is caused by tax service quality and the lack of tax morale that encourages active tax resistance. To increase compliance of taxpayers, the tax authority needs to adjust a cooperative compliance approach on tax regulation based on trust and dialogue between both parties.

\section{References}

Castro, L., \& Scartascini, C. (2015). Tax compliance and enforcement in the pampas evidence from a field experiment. Journal of Economic Behavior \& Organization, 116, 65-82. https://doi.org/10.1016/j.jebo.2015.04.002

Deakin, S., Gindis, D., Hodgson, G. M., Huang, K., \& Pistor, K. (2017). Legal institutionalism: Capitalism and the constitutive role of law. Journal of Comparative Economics, 45(1), 188200. https://doi.org/10.1016/j.jce.2016.04.005

Dewi, F., \& ER, M. (2019). Business Process Maturity Level of MSMEs in East Java, Indonesia. Procedia Computer Science, 161, 1098-1105. https://doi.org/10.1016/j.procs.2019.11.221

Duy, N. V., \& Tran, T. Q. (2021). The influence of international standards on SME tax compliance in Vietnam. Finance Research Letters, 40, 101750. https://doi.org/10.1016/j.frl.2020.101750

Hajawiyah, A., Suryarini, T., Kiswanto, \& Tarmudji, T. (2021). Analysis of a tax amnesty's effectiveness in Indonesia. Journal of International Accounting, Auditing and Taxation, 44, 100415. https://doi.org/10.1016/j.intaccaudtax.2021.100415

Hanlon, M., \& Heitzman, S. (2010). A review of tax research. Journal of Accounting and Economics, 50(2), 127-178. https://doi.org/10.1016/j.jacceco.2010.09.002

Huong, V. Van, \& Cuong, L. K. (2019). Does government support promote SME tax payments? New 
evidence from Vietnam. Finance Research Letters, 31. https://doi.org/10.1016/j.frl.2018.11.017

Jimenez, P., \& Iyer, G. S. (2016). Tax compliance in a social setting: The influence of social norms, trust in government, and perceived fairness on taxpayer compliance. Advances in Accounting, 34, 17-26. https://doi.org/10.1016/j.adiac.2016.07.001

Juniarti, J, Noersanti, L., \& Susanti, E. H. (2019). The Impact of Modern Tax System Against Transport Workers Taxpayer Compliance Online. Proceedings of the 5th Annual International Conference on Accounting Research (AICAR 2018). https://doi.org/10.2991/aicar-18.2019.48

Kirchler, E., Maciejovsky, B., \& Schneider, F. (2003). Everyday representations of tax avoidance, tax evasion, and tax flight: Do legal differences matter? Journal of Economic Psychology, 24(4), 535-553. https://doi.org/10.1016/S0167-4870(02)00164-2

Lagravinese, R., Liberati, P., \& Sacchi, A. (2020). Tax buoyancy in OECD countries: New empirical $\begin{array}{llll}\text { evidence. Journal of } & 103189 .\end{array}$ https://doi.org/10.1016/j.jmacro.2020.103189

Le, D. T., Malesky, E., \& Pham, A. (2020). The impact of local corruption on business tax registration and compliance: Evidence from Vietnam. Journal of Economic Behavior \& Organization, 177, 762-786. https://doi.org/10.1016/j.jebo.2020.07.002

Li, J., Wang, X., \& Wu, Y. (2020). Can government improve tax compliance by adopting advanced information technology? Evidence from the Golden Tax Project III in China. Economic Modelling, 93, 384-397. https://doi.org/10.1016/j.econmod.2020.08.009

Luksic, J. (2020). The extensive macro labor supply elasticity: Integrating taxes and expenditures. European Economic Review, 121, 103325. https://doi.org/10.1016/j.euroecorev.2019.103325

Nugroho, M. A. (2015). Impact of Government Support and Competitor Pressure on the Readiness of SMEs in Indonesia in Adopting the Information Technology. Procedia Computer Science, 72, 102-111. https://doi.org/10.1016/j.procs.2015.12.110

Oliviero, T., \& Scognamiglio, A. (2019). Property tax and property values: Evidence from the 2012 Italian tax reform. European Economic Review, 118, 227-251. https://doi.org/10.1016/j.euroecorev.2019.05.015

Otusanya, O. J. (2011). The role of multinational companies in tax evasion and tax avoidance: The case of Nigeria. Critical Perspectives on Accounting, 22(3), 316-332. https://doi.org/10.1016/j.cpa.2010.10.005

Purnawan, A., Khisni, A., \& Witasari, A. (2019). Politics of Law of Imposing Income Tax (PPh) Based on Micro, Small and Medium Enterprises (MSMEs) with Justice Value Base to Increase Voluntary Tax Compliance in Industrial Revolution 4.0 Era. Proceedings of the 3rd International Conference on Globalization of Law and Local Wisdom (ICGLOW 2019). https://doi.org/10.2991/icglow-19.2019.73

Robbins, B., \& Kiser, E. (2020). State coercion, moral attitudes, and tax compliance: Evidence from a national factorial survey experiment of income tax evasion. Social Science Research, 91, 102448. https://doi.org/10.1016/j.ssresearch.2020.102448

Saad, N. (2014). Tax Knowledge, Tax Complexity and Tax Compliance: Taxpayers' View. Procedia - Social and Behavioral Sciences, 109, 1069-1075. https://doi.org/10.1016/j.sbspro.2013.12.590

Soewardi, T. J., \& Ananda, C. F. (2015). The Transformation of Bea Acquisition Rights to Land and Buildings (BPHTB): Case Study in Kediri City of East Java. Procedia - Social and Behavioral Sciences, 211, 1179-1185. https://doi.org/10.1016/j.sbspro.2015.11.157 
Szablowski, D., \& Campbell, B. (2019). Struggles over extractive governance: Power, discourse, violence, and legality. The Extractive Industries and Society, 6(3), 635-641. https://doi.org/10.1016/j.exis.2019.06.009

Tondani, D. (2009). Universal Basic Income and Negative Income Tax: Two different ways of thinking redistribution. The Journal of Socio-Economics, 38(2), 246-255. https://doi.org/10.1016/j.socec.2008.10.006

Torgler, B., \& Schneider, F. (2009). The impact of tax morale and institutional quality on the shadow economy. Journal of Economic Psychology, 30(2), 228-245. https://doi.org/10.1016/j.joep.2008.08.004

Yáñez-Araque, B., Sánchez-Infante Hernández, J. P., Gutiérrez-Broncano, S., \& Jiménez-Estévez, P. (2021). Corporate social responsibility in micro-, small- and medium-sized enterprises: Multigroup analysis of family vs. nonfamily firms. Journal of Business Research, 124, 581592. https://doi.org/10.1016/j.jbusres.2020.10.023 